\title{
Pentecostal Ecumenism: The Legacy of David Du Plessis
}

\author{
Dr. Kelebogile Thomas Resane \\ Research Fellow \\ Department of Historical \& Constructive Theology \\ Faculty of Theology \& Religion \\ University of the Free State, Bloemfontein \\ South Africa \\ Email: resanekt@ufs.ac.za \\ DOI: https://doi.org/10.46222/pharosjot.102031
}

\begin{abstract}
This article retrieves the historical ecumenical endeavours of David Du Plessis - the South African who ended being an American citizen and the Assemblies of God credentialed minister. From the Afrikaans community of the Apostolic Faith Mission to the World Pentecostal Fellowship, Du Plessis laboured extensively for the acceptance of the Pentecostal and Charismatic faith into the world ecumenical formations such as World Council of Churches, mainline Protestantism and the Catholic Church. Rejected by his own denomination for ecumenical engagement, he blazed the way for the current Pentecostal ecumenical participation and ecumenism. He built the legacy that has enhanced Pentecostal and Charismatic experience and made it accommodated and understood in different ecumenical formations. The legacy he left behind includes opening doors for dialogues between Pentecostals and other Christian formations, demystifying Pentecostal fears of Christian brotherhood on a global scale, and creating some synergy between Pentecostals and nonPentecostals as the fulfilment of Christ's desire that 'They might be One.' Although not a theologian, Du Plessis paved the way for theology of dialogue as a way of enforcing Christian fraternity especially in impacting communities with the love of Christ.
\end{abstract}

Keywords: Du Plessis, Pentecostal, Charismatic, Church, ecumenism, dialogue, legacy.

\section{Introduction}

There are many unsung heroes, champions who contributed enormously towards God's mission on earth. They are men and women whose names are not mentioned in church history books and are hardly quoted in scholarly manuscripts of our days. Some their names are not inscribed on the halls of fame; and have no statues, masts or monuments to commemorate them. The objective of this article is to capture the modern Pentecostal Movement's ecumenical embrace - a legacy of the South African born 'morning star' of Pentecostal ecumenism by the name of David Johannes Du Plessis. Although David Du Plessis became well-known as 'Mr. Pentecost' I wonder how many theology or Bible school students, especially those from Pentecostal tradition read or study about him? His cultural background, divine calling, ecumenical convictions, and passionate baptism in the Holy Spirit had opened doors into world Christianity and elevated him to the higher royal thrones of bringing the message of Pentecost to the world. His global missio-ecclesial outlook took him to the powerful position as the Secretary of the World Pentecostal Fellowship. His unwavering convictions on Pentecostal experiential theology, ecumenical beliefs, and inclusive ideals are all discussed as a trail blazer for Pentecostalism to be sitting within the ecumenical formations of our day and did very important work in the same vein as the early Church fathers in work for Orthodoxy (Nicolaides, 2010). His legacy carries on and many current Pentecostal and ecumenical leaders appreciate his stance during the time when Pentecostalism saw any outsider (doctrine, theology, church) as something worldly and not fit for the kingdom of God. There is no doubt 
that Du Plessis lived and led under the conviction that 'Pentecostalism started in most places as an ecumenical renewal movement' (Vondey, 2011:319). Today many Pentecostals celebrate this legacy as it has opened broad-mindedness and ample opportunities for missional expressions and exertions.

\section{A brief biographical sketch}

David Johannes Du Plessis was born on the $7^{\text {th }}$ February 1905 in Twenty-Four Rivers on the outskirts of Cape Town in South Africa (Howard, 2004). His parents were the descendants of French Huguenots (later becoming Afrikaners). Their conversion led to expulsion from the Dutch Reformed Church. They were influenced by the Pentecostal pioneers John G Lake and Thomas Hezmalhalch. These two pioneers were the products of the ministry of John Alexander Dowie from Zion in Illinois, USA. His parents became missionaries in Lesotho, and later in Ladybrand just outside the borders in South Africa (Howard, 2004) Du Plessis became a naturalised American citizen. It was due to his time in the United States of America that he launched into Christian formations that connected him to the wider ecumenical communities such as the World Council of Churches, the Roman Catholic Church, the World Pentecostal Fellowship and others Blumhofer, 1993).

At an early age in Ladybrand, he worked as a carpenter with the Black people in his area. He was impressed by Black believers' expressive joy and this caught his attention so that at the age of twelve, he got converted (1916) through the dramatic thunderstorms where "calling upon the name of Jesus' convinced him to embrace Jesus wholeheartedly. Through the ministry of Charles Heatley, in 1918, Du Plessis was baptised with the Holy Spirit as evidenced by speaking in tongues, and consequently with strong conviction, he preached both inside and outside the church. In 1932, at the age of twenty-five, he was ordained as a minister of the Apostolic Faith Mission, and from 1935 to 1947, he worked as a General Secretary of the Apostolic Faith Mission. It was during this time that he regularly rubbed shoulders with the itinerant British Pentecostal evangelist, Smith Wigglesworth who regularly visited South Africa. In 1935, he became the General Secretary of the denomination where he promoted the idea of having closer ties between the AFM and South Africa's three 'sister' churches (Clark, 2007).

\section{Transition from national to international ministry exposure}

It was through the prophetic ministry of Wigglesworth that Du Plessis received a new direction of his life destiny. Spittler (2002) puts it this way:

During the visit Smith Wigglesworth shared a prophecy that was destined to redirect his life. The prophecy was that this young man from South Africa would be chosen of God to travel to the United States and be a major catalyst of the Charismatic Renewal in the traditional denominations. Wigglesworth pinned this young man to the wall of his AFM office in 1936 and told him where God would lead him for decades to follow. All he had to do was to remain obedient and faithful to the Lord.

Harper (1965:47) expands the prophecy by Wigglesworth on Du Plessis:

Suddenly the door of [to David's AFM office] flew open and in walked Smithy Wigglesworth. He commanded the startled du Plessis to come out from behind the desk. Laying his hands on his shoulders he pushed him against the wall and began to prophesy: 'You have been in Jerusalem long enough... I will send you to the uttermost parts of the earth... You will bring the message of Pentecost to all churches... God is going to revive the churches in the last days and through them turn the world upside down.

His first international exposure was in 1937, addressing the General Council of the Assemblies of God in Memphis, Tennessee. This took him another decade when he gave a keynote address at the first Pentecostal World Conference in 1947, held in Zürich, Switzerland. These 
two events started to expose and open Du Plessis' eyes for the worldwide ministry. He resigned as the secretary of Apostolic Faith Mission and moved his family to Basel in Switzerland. A year later he moved to the United States of America (Blumhofer, 1993; Du Plessis, 1970).

David encountered the once critic of Pentecostalism turned a supporter, John A. McKay, a Presbyterian heading Princeton Theological Seminary. This man became Du Plessis's gate into the world of ecumenism as many ecumenical doors started to open for Du Plessis. In his own words, Du Plessis uttered about their relationship as 'one of those rare and precious relationships in which both parties fully perceive the truth about the other-differences and all-and are in a twinkling of an eye united forever in the Spirit.' ${ }^{\prime 1}$ The era was not that of a smooth sailing for Du Plessis. It was at the time when Pentecostals were parochial, "holier than thou', anti-unity of all believers, and of course irrational and deeming education lowly. This sentiment is expressed by Constantineanu and Scobie, (2018:10-11) that:

\begin{abstract}
Some Pentecostals have questioned the validity of ecumenical work and have raised objections to engagement with other churches. Pentecostals believe the Christ is recognized spiritually not visually and accuse some churches of betraying essential elements of the gospel. Moreover, the Pentecostal experience is deemed to have breathed life into the church as the church is known only by the Spirit, those without the Spirit may be devoid of life (apostates).
\end{abstract}

However, Du Plessis was accepted ecumenically because of his articulation of Pentecostal experience. He became popular within Pentecostalism, promoting Pentecostalism within ecumenical and denominational Christian platforms. This involvement earned him the nickname, 'Mr Pentecost.' His popularity was growing, and he was gaining influence and momentum simultaneously with the growth of the Charismatic Movement. Pentecostalism led by Du Plessis and the Charismatic Movement led by Bennet simultaneously conscientised both the Ecumenical Movement and the Catholic Church about the Holy Spirit experience. Du Plessis was rejected by the wider evangelical spectrum due to his relationship with the ecumenists, yet 'he still succeeded in popularizing the Charismatic movement among the mainline denominations' (Spittler, 2002:250-254). Hayford and Moore (2006:211) indicates that "By 1970 , it was estimated that $10 \%$ of the mainline' s clergy and over one million church members received Spirit baptism".

\title{
Conflicts on the way
}

Immediately after arrival in United States, the Assemblies of God presented him with ministerial credentials, though some leaders were already rejecting and denouncing his ecumenical interactions and activities (Spittler, 2002). He was fiercely repudiated by the World Pentecostal Conference, which is currently called the World Pentecostal Fellowship. The resistance from within (Assemblies of God) was heightened in 1962 when their mouthpiece known as Pentecostal Evange/ carried an article claiming that the ecumenical movement was a means through which to form 'a harlot church of Revelation'. The article stipulated:

The National and World Council of Churches are the crystallisation of this apostasy, for they do not believe in the inspiration of Scriptures nor are they true to the Person of Jesus (Boyd, 1962:19).

Regardless of this internal rejection by his own denomination, Du Plessis' ministry grew transdenominationally and ecumenically. As a result, in 1962, the Assemblies of God withdrew his ministerial credentials without substantiating any reasons or facts. Du Plessis did not retaliate but 'picked up the lemons thrown unto him and made sweet lemonade out of them'. He saw this as a release from the Pentecostal cage as the demands for his ministry was huge outside this cage. The withdrawal of Assemblies of God credentials was rescinded and re-issued in 
1979. It seems by that time Assemblies of God was starting to open up for ecumenical understanding (Ziefle, 2012).

\title{
Ecumenical encounters
}

The decade of 1960-1970 was like a zenith of Du Plessis' ecumenical ministry. He became internationally acclaimed and travelled extensively preaching the message of Pentecost. Wigglesworth's prophecy was fulfilled in his life. He was a preacher without ministerial credentials, or a missionary sent out without any Missions Board. This was the era of the birth and wildfire spread of the Charismatic Movement, and Du Plessis became the herald of the new message of experience throughout the world. His passionate endeavours of Pentecostal ecumenism are captured by Vondey (2011:322):

\begin{abstract}
Du Plessis's significant connections with the Roman Catholic Church, the World Council of Churches (WCC), and the Charismatic movement ultimately led to the first official dialogue between Pentecostals and the Roman Catholic Church, a pioneering event that became the model for subsequent ecumenical conversations with Pentecostal participation. The new ecumenical exposure significantly helped interpret the changing face of twentieth-century Pentecostalism to those outside of the movement.
\end{abstract}

Vatican II came and was concluded during this era. The tensions between the Pentecostals and the Catholic Church, together with other mainline denominations was felt. The wedge between these traditions was known, experienced and emotionally felt. Pentecostals regarded mainline denominations as the beast and scarlet woman of Revelation doomed to the lake of fire (Harper, 1965:47). Being the uncredentialled minister, offered him the opportunity to lead Pentecostals into dialogues with the Catholic Church. To this day, the longest most significant international dialogue is the Roman Catholic-Pentecostal one. Diverse theological issues were handled and discussed through a half of a century. The first Dialogue (1972-76) deliberated on Spirit baptism and spiritual gifts, Christian initiation, and worship. The second Dialogue (1977-82) deliberated on the relationship of scripture and tradition, faith and reason, speaking in tongues, divine healing, and the role of Mary. The third Dialogue (1985-89) concluded with the widely acclaimed document, Perspectives on Koinonia, which focused on ecclesiology, encapsulating topics such as the nature of the church, the sacraments, and the communion of saints. The fourth Dialogue (1990-97), immersed itself on the questions relating to evangelisation, proselytism, as well as the opportunities and challenges of common witness. The fifth Dialogue (1998-2006) culminated into the production of the massive document, On Becoming a Christian, focusing on conversion, faith and Christian initiation, Christian formation and discipleship, Spirit baptism and experience in Christian life and community, which is the current stage of discussion, the ongoing conversation between these two traditions. These dialogues were met with some criticisms, but they surged on, and in a nutshell:

helped Pentecostals understand how to perceive and formulate much of their own identity, consolidating their renewed ecumenical commitment, and leading to dialogue with other mainline Protestant bodies (Vondey, 2011:324).

The Catholic-Pentecostals dialogues are well documented as they happened after every five years. Du Plessis participated as a chairman in the first two dialogues of 1972-1976 and 19771982. He was at the forefront of the initiatives, together with a designated Catholic leader, Father Kilian McDonnell. So, in these dialogues, Pentecostals were neither observers or spectators, but full participants, and in some cases, even acted as facilitators.

The climax of these Dialogues was experienced in 1975 Congress on Charismatic Renewal in the Catholic Church in St. Peter's Basilica. There were no official Pentecostal leaders at this event despite all efforts made to invite them along. The conference continued successfully, and the Charismatic Movement was officially accommodated within the Catholic faith. 
The roots and the escalations of these dialogues took place under the inspiration of Pope John Paul II. He was the Pope of Dialogue 'a prophet of nonviolence, a wily diplomat, a political hope' (Weigel 1999:440); and reading through some of his Insegnamenti di Giovanni Paolo II, of the $80 \mathrm{~s}$, one picks up that his theology of dialogue was an inspiration to ecumenical dialogues. For him, dialogue means reciprocal communication between persons, and that it encompasses some complex of human activities founded on respect and esteem for different religious traditions, a means of mutual friendship and joint efforts for the sake of shared goals.

\begin{abstract}
It implies bearing witness to one's own religious values and a readiness to cooperate with others for the betterment of humanity. It means discovering areas of convergence and divergence among religions, and where circumstances permit, a sharing of spiritual experiences and insights (Insegnamenti di Giovanni Paolo I/ 1992:393).
\end{abstract}

For Pope John Paul, ecumenism was possible through dialogue, since dialogue helps people to learn from one another and to go more deeply into the truth. Some authors even allude to the fact that the Pope was very supportive of the Charismatic Movement both within and outside the Catholic Church. It is recorded that he also gave his blessing to the movement in 1987 (Hocken, 2001; Hayford \& Moore, 2006:217-247).

Du Plessis' Pentecost's conviction expanded beyond the Catholic circle. He attended the International Missionary Council held at Willingen, Germany, in 1952. There John A. Mackay vouched for Du Plessis and introduced him to the delegates as 'my great Pentecostal friend.' Prior to this in 1947, he attended the first World Pentecostal Conference as an official delegate of Apostolic Faith Mission of South Africa. He was asked to convene the same conference the following year of 1948 and asked to serve as its secretary, the responsibility he shared for the conferences of 1952 and 1958 (Quebedeaux, 1976:93).

The influence and the legacy of Du Plessis became extensive beyond the traditional churches' borders when in 1954, he was invited to attend the second assembly of World Council of Churches in Evanston by Visser't Hooft, not as a delegate or attendee, but as a staff member of the conference. This is where he acclaimed the name 'Mr Pentecost.' Then in 1961, he was also at the third assembly of World Council of Churches in New Delhi, participating as a Pentecostal observer (Harper, 1965:53; Quebedeaux, 1976:93). One of the notable rallying calls of this Assembly was Visser't Hooft's 'us and them' notion that represents a worldly standard imposed on the church' (1985:491). Those were the days when Pentecostals felt marginalised, rejected, and abhorred by mainstream Christianity. This rejection by traditional and established churches was based on doctrinal differences and the emphasis on experience. Their charismatic experiences were labelled as 'sensual', 'devilish' and 'deluded', and in some cases ministers claiming the experiences such as glossolalia and healing were excommunicated, suspended or having their ministerial credentials or licenses withdrawn.

In reaction, Pentecostals separated themselves further from ecumenical exclusivity, due to their rejection by the churches (Anderson, 2014:252-253). They 'tended to be wary of interreligious cooperation' (Poloma \& Green, 2010:166), as they were ecclesiastically stigmatised as heretics to be avoided by all means possible. This state of affairs is further described by Hollenweger (2012:209) that in those days, 'nobody wanted to talk to the Pentecostals, and the Pentecostals didn't want to talk to any of the other churches because they saw them as a lost cause.' The majority of Pentecostal churches opted not to participate in any ecumenical organization, because of their restorationist perspective on the history of the church that views existing churches as depraved and compromising sin. This led to the open door for sectarian tendencies putting emphases on eschatological position that feared ecumenical contact. On the other hand, there was an underlying fear that 'ecumenism allows for a 'weakening of Pentecostal enthusiasm, compromise of doctrinal standards, incompatibility of purpose, [and] syncretistic tendencies' (Davidsson, 2012:165). 
Despite this elusive sentiment, the legacy of 'Mr Pentecost' spread its wings further into some international dialogues. For instance, the international dialogue $(1996-2000)$ between the World Alliance of Reformed Churches (WARC) and Pentecostal leaders is worthy of note. Its Report was finally consolidated and in its conclusion these dialogists agreed that friendships have been established across denominational lines, and that:

\begin{abstract}
These friendships have expanded beyond the realm of everyday life into the recesses of our common spiritualities and our ecclesial experiences. Genuine ecumenism begins when Christians find each other and learn to enter into the lives of one another (Report 2001. Par 96).
\end{abstract}

A second benefit of this Dialogue has been the individual studies that have been offered in the form of papers presented. These papers conscientised the Christian world about the existence of this Dialogue by making some ways into some reputable journals. This is a deposit of legacy left for the next generations of researchers and scholars. Thirdly, the Dialogue has been able to give Christian solidarity and support in all the regions where meetings were convened. In other words, this Dialogue presented opportunities for humanitarian services indiscriminately. So, dialogues break human boundaries that hamper diaconal offerings of love deserved by humanity carrying imago Dei. Finally, the Dialogue opened the realisation of the critical necessity for continuing contact between the Reformed and the Pentecostals. 'With the completion of this report, the participants in this Dialogue wish to encourage others in their respective communities to join in this mutual exploration' (2001 par. 99).

The bottom line is that this Dialogue dispelled stereotypes and it corrected misunderstandings. The participating dialogists started to recognise in each other the fullness and the reality of apostolic faith and witness. They acknowledged the ensuing tensions between Pentecostals and the Reformed believers in some parts of the world.

The second round of the Dialogue was extended between 2001 and 2011, addressing different themes from 2002. It was initiated and spearheaded by the David Du Plessis Center for Christian Spirituality at Fuller Seminary in Pasadena, California, USA. It was held in Amsterdam, the Netherlands. It began with the theme 'Experience in Christian Faith and Life.' Through the decade, the Dialogue focused on self-identity of the two traditions. The highlights were' more on the "us", who we are together, rather than on those things that distinguish us from one another' (2012 par. 173). The ensuing questions were 'What does this mean for us?' rather than 'what might this mean for them?' (par. 174),

The outcomes of this Dialogue clearly surfaced the reality that there is a common ground in many aspects of faith and church life. Self-understanding and engaging together for and in life activities should be the focus when together we render services to the communities of the world.

The third round of this Dialogue started in 2014 and held in Hungary. World Alliance of Reformed Churches (WARC) has now become World Communion of Reformed Churches (WCRC).

Du Plessis' legacy of Pentecostals and other ecumenical bodies also exerted itself, when in 2005, Pentecostals entered into dialogue with the Lutheran World Federation under the theme: 'Encountering Christ'. Jean- Daniel Pluss chaired the Pentecostal dialogue table. The Dialogue was completed in 2010 and a 'report was issued at the Lutheran World Federation under the title; Lutherans and Pentecostals in Dialogue' (Hunter 2015:3). There are current and recent dialogues with no final reports compiled yet. For instance, there are some informal talks between the Patriarchate and Pentecostal (2010-2012), with consultation planned for 2015 in Oxford. The commencement of Pentecostals and World Baptist Alliance Dialogue (2011) in Birmingham, Alabama extended the legacy of Du Plessis. The dialogue initiatives are ongoing and at the end of the day, Christ's prayer for unity is slowly but surely realised, and the dream of 'Mr Pentecost', Du Plessis is realised and continues to take shape. Creemers 
(2015:4) points to the fact that 'most of these (and other) new ecumenical relationships are still in a formative stage and their theological conversations are largely scratching the surface'.

Consequently, Pentecost had invaded the denominations. The charismatic Movement had been born in 1960 when Dennis Bennett had been baptised in the Spirit in Van Nuys, California and a major influence on its growth was 'Mr. Pentecost.' Du Plessis' conviction was not to engage in theological debates or practices, but to go out to those who disagreed with him and offer forgiveness. The results of these ecumenical deliberations led to collections of documents, memorandums of understanding, specified academic Pentecostal centers in some institutions of learning etc. A good example to the latter is the David Du Plessis Center for Christian Spirituality at Fuller Seminary in Pasadena, California, USA. The bottom line is that consequently 'a collection has grown of theological themes which bring ecumenical dialogue partners closer together' (Creemers, 2015b:4).

\section{The felt and realised legacy}

Du Plessis is undoubtedly one of the shapers of Christianity in the twentieth century. He became an icon within the Pentecostal Movement, the Charismatic Renewal and the Ecumenical Movement. He fostered closer understanding between the Pentecostals and the mainline Christianity (Cauci, 2004). The classical Pentecostalism, due to Du Plessis' influenced enthusiastically embraced calling and gifting as a qualification for the recognition of a leader. For instance, in February 2015, Pentecostal/Charismatic Churches of North America (PCCNA) informally stipulated that any new commission must embody 'divine initiative, visionary calling, passion, and obedience of faith' (Hunter, 2003:33). This stance was instigated by Du Plessis' hypothesis of his book, The Spirit Bade Me Go. Looking back, one can justifiably conclude that due to Du Plessis' ecumenical endeavours, Pentecostals started to move beyond their circles and engaged conciliar ecumenism.

He laid important foundations, and demystified Pentecostal fears of Christian brotherhood on a global scale. Pentecostals, who from the time of their inception had maintained an antiecumenical stance had 'increasingly become open to ecumenical dialogue' (Plaatjies Van Huffel, 2017:9). This emphasis was carried over and built in the $20^{\text {th }}$ century when Du Plessis vigorously initiated engagement and dialogue with world Christian bodies. He became a de facto 'theologian of dialogue.' A man who could not use theology to validate, but experience to hypothesize. The baptism in the Holy Spirit consequent to conversion was his thesis to bring theologically diversified convictions into some form of symbiotic relationship - koinonia par excellence! He believed Christians should not live estranged from each other, as apartness from ourselves may lead into apartness from God. His conviction about this distance from each other resonated with what Crow (1982:78) expressed that 'we live in the midst of distrust and division instead of the love and affection of God.' But the doctrinal, confessional, and liturgical chasms that divide the churches should be bridged. God invites us 'to live the whole life in the whole community given in Christ' (1982:79).

Du Plessis' legacy is felt and realised as many South African Pentecostal formations demonstrate their commitment to ecumenism through membership of a number of regional, continental and international bodies such as The Evangelical Alliance of South Africa (TEASA), the South African Council of Churches (SACC), and many new ecumenical movements that are mushrooming, especially due to the need to address the COVID-19 pandemic challenges which have befallen the world. Apart from the Classical Pentecostal denominations, the Neo-Pentecostal churches that emerged in South Africa at the turn of the 1970 s experienced some phenomenal growth and ventured into some form of ecumenical partnerships. Jones (1990:109) attributes their growth to their dispensational theology and the focus on health and wealth gospel championed by pastor- preneurship approach. Some Pentecostal churches affiliated to Pentecostal World Fellowship are simultaneously members of the National Councils. A good example here is the Rev. Frank Chikane of the Apostolic Faith Mission who was once a General Secretary of South African Council of Churches. This 
Classical Pentecostal denomination is a full member of South African Council of Churches. Examples of the Neo-Pentecostal churches in full membership of South African Council of Churches include the likes of a famous Charismatic Church of Musa Sono, known as Grace Bible Church; and Rhema Bible Church under Ray McCauley. This Ray McCauley

\begin{abstract}
...emerged as one of the country's most opportunistic white neo-Pentecostal leaders, becoming president in 1985 of the newly created International Fellowship of Christian Churches, South Africa's largest association of charismatic and neo-Pentecostal churches (Duncan \& Egan, 2019:19).
\end{abstract}

McCauley took his church further into ecumenical circles by joining South African Council of Churches, something that made him to lose favour and support from many of his white antiliberal congregants. This liberal stance is probably instigated by the desire for reconciliation, which is impossible without church unity. Neo-Pentecostals such as McCauley would beat the same drum with Du Plessis that fellowship and prayer are not just the preparation for the real ecumenical tasks but are the ecumenical tasks themselves (Crow, 1982:80). For them, evangelism and discipleship are not just the proclamation, but 'a commitment to listen to others' (Fernando, 2001:36). Probably these Pentecostals who embrace ecumenism realise that a light shines better on the hill, and salt must be added into food to enhance the taste. One cannot make a difference from outside. Kerygma regarding the love of God cannot be an activity from the distance as stated also by the mainline founding Orthodox Church (Nicolaides,. The need is to come closer to see why the bush is burning. These Pentecostals heed Douglass' wisdom (in Kirkpatrick, 2010:93) that:

Ecumenism is also a work of love, a process of deep personal engagement with our brothers and sisters to the point where empathy and compassion flow naturally, where offences - present or historical - can be confessed and forgiven.

One legacy that Du Plessis left for Christendom is that within the faith itself, contact does not mean compromise. There is always 'contact without contamination' (Lutzer, 1980:31) whereby Christians, more so theologians, remain insulated, not isolated from the world's spiritual needs. A Pentecostal remains a Pentecostal within the liberals, conservatives, and Catholics, without ceasing to be Pentecostal. Du Plessis's indelible mark is that unity within the body is never driven or controlled by dogma. He himself was not an academic, but the ordinary Spiritled Pentecostal Afrikaner born of the stock that is internationally known for apartheid policy. For him, rubbing shoulders with people of different races and theological persuasions was not an enigma or anathema. He 'advocated Pentecostalism as a renewal agency' (Ziefle, 2012:54) rather than dogmatic epistemologies such as cessationism, fundamentalism, dispensationalism etc. For him, 'that they may be one' was the driving force:

David advocated a spiritual unity, rather than an organisational unity. Du Plessis always encouraged those in the traditional churches who were Spirit baptized to remain in their own tradition. He opposed the "come-outism" and encouraged Charismatics to change the tradition from within. However, clearly his mode was that of a 'missionary' who took the Pentecostal experience to receptive fields (Hunter, 2015:10).

Du Plessis' legacy for all Christian and non-Christian religions is that of the importance of dialogue. Historically Pentecostals are known for being difficult dialogists. Kasper (2004:25) highlights this fact that they 'are not always easy dialogue partners as some of them are always aggressive and proselytizing.' Despite that, Du Plessis' ecumenical connections and transcendental understanding came through dialogues. Although his dialogical engagement was on Pentecostal experience, today one can see how the dialogues between ecumenical bodies and Pentecostals had evolved and are bearing fruit towards Christian selfunderstanding and unity. For instance, there are different ecumenical dialogues with Pentecostals currently or in the recent past - all because of the foundational legacy left by Du 
Plessis. The 'wheel is still turning' towards the realisation and the outcomes of these dialogues.

Pentecostals and the mainstream Christianity had come closer to each other than ever before. Their synergy is the fulfilment of Christ's desire that 'They might be One.' The levels of suspicion for or towards each other are lowered, ecumenical co-operations are visible in missional endeavours to address the needs of the world and of course, in the proclamation of the Gospel. Ecumenism 'has created an atmosphere of mutual respect, openness and rapprochement among the churches, which have been deeply divided by history, theology, culture and geography' (Plaatjies Van Huffel, 2017:4, Aram, 1992:4). Apart from ecumenical endeavours among themselves, which were built in the twentieth century through the efforts of the likes of Du Plessis, the Pentecostals of the twenty-first century are vigorously engaged in dialogues regarding their identity and missional endeavours. They have come to the place of realising that 'their pursuit of Christian unity is inextricably linked with the formulation of their own identity' (Vondey, 2011:318).

Ecumenical dialogue has proved through Du Plessis's legacy that it is a cohesive power and is an effective tool to achieve coexistence, harmony, mutual understanding, and reducing prejudices (Campdepadrós-Cullell, Pulido-Rodríguez, Marauri, J \& Racionero-Plaza, 2021:1). At the end of the day, Du Plessis's vision of inclusive ecumenical community is continuing to shape the true community under the Lordship of Christ. This community in its diversities of doctrinal and experiential expressions is Christologically expected to live 'together in an osmosis of charisms and functions, under the guidance of the Holy Spirit' (Tillard, 1992:83). This is an eschatological journey, because the 'church is not yet at her destination. She still has her authentic hope ahead of her' (Ratzinger, 1987:25).

There is some significant collaboration of Pentecostals and the ecumenists in the area of theological education. Many Pentecostal teachers, preachers, and evangelists receive their theological training from the non-Pentecostal institutions, and the reverse is true. The new breed of Pentecostal leaders is progressively engaged in consolidation efforts of the twentieth century Pentecostal ecumenists such as Du Plessis and McGee. Their participation in these efforts are the efforts of 'repairing the damages done by an anti-intellectual attitude, exclusivist mindset, and lack of dialogue dominant among many classical Pentecostals' (Vondey, 2011:322).

A typical example is that of the German evangelist, Reinhard Bonnke, who though unapologetically Pentecostal, received his training from the evangelical Bible College of Wales. One example closer is the twentieth century South African Pentecostal preacher, Nicholas Bhengu who received his theological training at non-Pentecostal evangelical Dumisa Bible School (Watt, 1992:34) - now known as Union Bible Institute. Through theological training in diverse institutions, Pentecostal students learn and appreciate ecumenical ideals, and 'leap into' their ministry fields with this mindset. Many start to realise the importance and potency of ecumenical theology in ministerial and missional undertakings. The fact of the matter remains, as stated by the Ecumenical Review in Oslo Report: 'Theology is an imperative for ecumenism. And ecumenism is an imperative for doing theology today' (Werner, 2012:397). In all these endeavours through theological education, decisive steps are taken to ensure that 'Pentecostal preachers are to be shaped in such a way that Pentecostalism does not lose its distinctiveness' (Resane, 2018:6).

These early attempts by Du Plessis definitely had made some remarkable steps towards the realisation, identifying and formulating of Pentecostal theology which is communitarian in nature. Isolation and independence are not consonant with biblical ecclesiology. Pentecostalism of the postmodern era sees itself as united ecclesia, meaning 'we are all one in Christ.' Koinonia is broader than denominational traditions or any confession. Pursuing own denominational goals as a way of transforming societies for good, is slowly becoming an insurmountable mountain to climb. 
The "body of Christ" suggests "interdependence" in the church of God. Unfortunately, today, most ecumenical pursue denominational goals even when it is at the detriment of the entire "body of Christ." (Primacy, 2020:86).

Du Plessis was not just a man of koinonia. He was not a spectator in the 'no man's land' trapped between the world of ecumenism and Pentecostalism. He was actively involved, a leader by dedication and demonstration. Like Jesus during the Upper Room Discourse, around the Supper Table, engaging his disciples; Du Plessis was of the conviction that participation involves engagement. During the Discourse, we see even Peter particularly engaged, even to the point of arguing with Jesus about foot washing and fierce resistance is even offered when told of his denial of his Master (Corrigan, 2016:21).

Du Plessis' legacy of theology of dialogue has, and still continues to make a positive contribution towards the defeat of theology of triumphalism. The two sides of the fence (Mainline Christianity and Pentecostalism) imbibed a theology of triumphalism where pointing fingers at each other due to the mentality of 'us' and 'them' prevailed. This mentality sacrifices the Christian virtues encased in the fruit of the Spirit (Galatians 5:22), especially humility, gentleness, and love. The early Pentecostals emerged as a war against 'triumphalism of the 'us and them' mentality in other churches, while they themselves have also developed a new form of triumphalism' (Courey, 2015:216). It is unfortunate as this attitude has articulated itself into what Kgatle (2021:142) calls 'triumphalist theology which has a hand in the abuse of power by some NPCs in South Africa.' By NPCs here it is meant New Prophetic Churches that are currently making some indelible marks on South African Christian landscape. Du Plessis' character and behaviour stands in juxtaposition with this mentality since he exhibited the character of Christ by going where other Pentecostals of his day would regard as Satan's territory.

\section{Conclusion}

Pentecostals are in various ways participants - either as individuals, communities, or denominations in some form of ecumenical formations. This is not a destination but a journey that started out of experiential reservations, triumphalist convictions, and retractions into some emotional and spiritual cocoons. We need to bear on mind that:

\footnotetext{
...there is one significant characteristic associated with all Christian traditions - Catholic, Orthodox, Protestant, Evangelical, Pentecostal and Charismatic. This is the Pentecostal experience of the indwelling of the Holy Spirit accompanied by different kinds of manifestations of the Spirit. (Onyinah Aniyah, 2013).
}

It took one man to break out of the shell, and leap into the task of bringing the understanding of baptism in the Holy Spirit to the traditional ecumenical movement - both Protestant and Catholic. David Du Plessis broke the ice to the point of being stripped of ministerial credentials by the denomination that he submitted himself to (Assemblies of God) in United States of America. He vigorously defended Pentecostal experience before the highly and theologically organized church formations, pointing out the genuineness of the experience of the Holy Spirit consequent to conversion. He was a dialogist, not just as a presenter, but also as an organizer of dialogues, conferences, colloquiums, and conventions. Hollenweger (2012:209) gives a remarkable summary about Du Plessis' ecumenical endeavours:

David du Plessis, a pioneer in ecumenism, has been instrumental in both these changes. He went to the Catholics. He went to the World Council of Churches. He went to all the universities. And the fact that he was a reasonable man and a Pentecostal astonished many people. They thought Pentecostals were all a little crazy and could not think properly. But when they 
got to know him, they realized that it is possible to speak in tongues and be a critical scholar.

Amid suspicions, reservations, abhorrences, and heretic 'labelings', he stood the ground to defend and validate Pentecostal substantiality. He was convinced that one must 'follow the work of the Spirit to identify new arenas where Christians are finding one another, often by working together to meet the needs of the wider community' (citing Douglass in Kirkpatrick, 2010:93). He laid the foundations for Pentecostal ecumenism and cleared the rocky paths towards acceptance of Pentecostal theology as a reality to be reckoned with. Through dialogues he initiated, Pentecostalism was better understood and accepted by ecumenists who formerly criticized them as being heretics. He demystified Pentecostal fears of Christian brotherhood on a global scale and created a Mosaic scenario of the desire of coming closer to see why 'the bush is burning?'. He changed the attitude of cowardly running away from the real issues and replaced them by coming closer through dialogue. Today, Pentecostals are becoming the 'salt of the earth' by participation with ecumenists in God's missional work to alleviate human miseries experienced all over the world. These miseries can be those of natural causes such as floods, poverty alleviation, earthquakes etc. They may be of a pandemic nature such as HIVIAIDS, COVID-19 and sporadically of those with an epidemic nature such as leprosy, stomach diseases etc. In some situations, there are intellectual needs addressed by Pentecostals in collaboration with other ecumenists such as inter-alia education, community developments. Indeed, Du Plessis's legacy should be appreciated as it can be observed that 'in many parts of the world Pentecostals occupy positions of power in politics, businesses and professional vocations' (Resane, 2018:4).

The legacy of Du Plessis is continuing to bear fruit as Pentecostals are 'breaking out of their shells', and the ecumenists are opening their arms to welcome them around the table for a meaningful dialogue, not much on theological differences, but on how to make Christ real in this hurting world. We are grateful for the efforts of David du Plessis. What a legacy he has left us!

\section{References}

Anderson, A.H. (2014). An Introduction to Pentecostalism, Global Charismatic Christianity. New York: Cambridge University Press.

Aram, K. (1992). Conciliar fellowship: A common goal, Geneva: WCC Publications.

Blumhofer, E. L. (1993). Restoring the Faith: The Assemblies of God, Pentecostalism, and American Culture. Urbana and Chicago: University of Illinois Press.

Boyd, F.M. (1962). 'Ecumenicity: False and True.' Pentecostal Evangel \#2526 (October 7, 1962), 19.

Campdepadrós-Cullell R, Pulido-Rodríguez M.A, Marauri J, \& Racionero-Plaza, S. (2021). Interreligious Dialogue Groups Enabling Human Agency, Religions, 12, 189.

Cauchi, T. (2004). "David du Plessis 1905 - 1987". Revival Library.

Clark, M. (2007). Contemporary Pentecostal Leadership: The Apostolic Faith Mission of South Africa as Case Study, Cyberjournal for Pentecostal-Charismatic Research (16),

Constantineanu, C \& Scobie, C.J (eds). 2018. 'Pentecostal Identity, Spirituality, and Theology' (p. 1-20) in Pentecostalism in the $21^{\text {st }}$ Century: Identity, Beliefs, Praxis, Eugene, OR: Cascade Books. 
Courey, D. J. (2015). What Has Wittenberg to Do with Azusa? Luther's Theology of the Cross and Pentecostal Triumphalism. London: Bloomsbury T \& T Clark.

Corrigan. P.T. (2016). Pedagogy and Koinōnia, The Pentecostal Educator: A Journal of the World Alliance for Pentecostal Theological Education, Spring 2016, 18-28.

Creemers, J. (2015a). 'Theological Dialogue with Classical Pentecostals: Challenges and Opportunities' in Gerald Mannion ed. Ecclesiological Investigations Volume 23. London: Bloomsbury T\&T Clark.

Creemers, J. (2015b). Dance to the Beat of Your Own Drum: Classical Pentecostals in Ecumenical Dialogue, Journal of the European Theological Association, 35(1), 58-68.

Crow Jr, P.A. (1982). Christian Unity: Matrix for Mission. New York: Friendship Press.

Davidsson, T.H. (2012). 'Lewi Pethrus' Ecclesiological Thought 1911-1974: A Transdenominational Pentecostal Ecclesiology.' A Thesis Submitted to the University of Birmingham for the Degree of Doctor of Philosophy, School of Philosophy, Theology and Religion, College of Arts and Law University of Birmingham (March 2012).

Douglass, J.D. (2010). Reflections on Ecumenism in the Calvin Year' (p.90-94) in Clifton Kirkpatrick ed. That They May All Be One: Celebrating the World Communion of Reformed Churches. Louisville: Westminster John Knox Press.

Duncan, G.A. \& Egan, A. (2019). The Ecumenical Struggle in South Africa: The Role of Ecumenical Movements and Liberation Organisations from 1966, Studia Historiae Ecclesiasticae, 45(1).

Du Plessis, D.J. (1970). The Spirit Bade Me Go. Plainfield, NJ: Logos Associates.

Du Plessis, D.J. (1977). A Man Called Mr. Pentecost. Plainfield, NJ: Logos International.

Experience in Christian Faith and Life: Worship, Discernment, Community, and Justice. The Report of the International Dialogue between Representatives of the World Alliance of Reformed Churches and Some Classical Pentecostal Churches and Leaders 2001-2011. Cyberjournal for Pentecostal-Charismatic Research \#21. [Available online at http://pctii.org/cyberj/cyberj21/WARC_2011d.html]

Fernando, A. (2001). Sharing the Truth in Love: How to Relate to People of Other Faiths. Grand Rapids: Discovery House Publishers.

Harper, M. (1965). As at the Beginning. Plainfield, NJ: Logos International.

Hayford, J.W. \& S.D. Moore. (2006). The Charismatic century: The enduring impact of the Azusa Street revival. New York: Warner Faith.

Hocken, P. (2001). 'The Charismatic Renewal' in Vinson Synan ed, The Century of the Holy Spirit: 100 Years of Pentecostal and Charismatic Renewal. Nashville: Thomas Nelson Publishers.

Hollenweger, W. (2012). Pentecostalism's Global Language, Renewal Journals, 3, 11-15.

Howard, R. (2004). "David du Plessis: Pentecost's 'Ambassador-at-Large'" in The Spirit and Spirituality: Essays in Honour of Russell P. Spittler, Volume 4, Continuum International Publishing Group, p. 272.

Hunter, H.D. (2003). Two Movements of the Holy Spirit in the $20^{\text {th }}$ Century? A Closer Look at Global Pentecostalism and Ecumenism, One in Christ, 38(1), January 2003. 31-39. 
Hunter, H.D. (2015). 'Pentecostal Ecumenical Pioneers: Select Case Studies in Leadership' [Available online

https://d3nr8uzk0yq0qe.cloudfront.net/media/upload/documents/2015/July/Pentecostal_Ecu menical_Pioneers_Select_Case_Studies_in_Leadership.pdf] (Accessed 14 August 2021).

Insegnamenti di Giovanni Paolo II, Vol. XIII, part 2, Città del Vaticano, Libreria Editrice Vaticana, 1992.

Kasper, W. (2004). That They May Be One: The Call to Unity Today. London: Burns \& Oates.

Kgatle, M.S. (2021. Triumphalist theology in the context of prophetic Pentecostalism in South Africa, Journal of the European Pentecostal Theological Association, 41(2), DOI: 10.1080/18124461.2021.1954273.

Lutzer, E.W. (1980). How in this World Can I Be Holy? Chicago: Moody Press.

Nicolaides, A. (2010). The Laos tou Theou - an orthodox view of the "people of God", HTS Teologiese Studies/Theological Studies, 66(1).

Onyinah, O. (2013). The Movement of the Spirit Around the World in Pentecostalism, Transformation, 30(4), Special issue: The Global Christian Forum: Life Together in Jesus Christ, Empowered by the Holy Spirit (October 2013), 273-286.

Plaatjies van Huffel, M.A. (2017). From conciliar ecumenism to transformative receptive ecumenism, HTS Teologiese Studies/ Theological Studies 73(3), a4353.https://doi. org/10.4102/hts. v73i3.4353

Poloma, M.M. \& Green, J.C. (2010). The Assemblies of God: Godly Love and the Revitalization of American Pentecostalism. New York: New York University Press.

Primacy, A.G.A. (2020). 'Paul's "Body" Metaphor in the books of Romans and 1 Corinthians and its relevance to Churches in Nigeria.' In John W.J. ed. Light in a Once-Dark World: Contemporary Issues in Nigerian Christianity. Volume 2. Hayesville, NC 28904 [Available online at www.biblicaltheology.com].

Quebedeaux, R. (1976). The New Charismatics; The Origins, Development, and Significance of Neo-Pentecostalism. New York: Doubleday.

Ratzinger, J. (1987). Church, Ecumenism, and Politics: New Endeavours in Ecclesiology. San Francisco: Ignatius Press.

Resane, K.T. (2018). Pentecostals and apartheid: Has the wheel turned around since 1994?', In die Skriflig 52(1), a2259. [Available online at https://doi. org/10.4102/ids. v52i1.2324]

Spittler, R.P. (2002). Dictionary of Pentecostal and Charismatic Movements. S.M. Burgess, rev ed. Grand Rapids: Zondervan Publishing.

Spittler, R.P. (2002). Du Plessis, David Johannes, Dictionary of Pentecostal and Charismatic Movements. S.M. Burgess, rev ed. Grand Rapids: Zondervan Publishing.

Tillard, J-M.R.(1992). Church of churches: The ecclesiology of communion. Collegeville, MN: Liturgical Press.

Visser'T Hooft, W. A. (1985). Triumphalism in the Gospels, Scottish Journal of Theology, 38(4), 491-504.

Vondey, W. (2011). Pentecostals and ecumenism: becoming the church as a pursuit of Christian unity, International Journal for the Study of the Christian Church, 11(4), 318-330 
Watt, P. C. (1992). From Africa's Soil: The Story of the Assemblies of God in Southern Africa. Cape Town: Struik Christian Books.

Weigel, G. (1999). Witness to Hope: The Biography of Pope John Paull II. London: Harper Collins Publishers.

Werner, D. (2012). Oslo: The Future of Theology in the Changing Landscapes of Universities in Europe and Beyond, Ecumenical Review, World Council of Churches. Oxford/Malden: Blackwell Publishing

Word and Spirit, Church and World. The Final Report of the International Dialogue between Representatives of the World Alliance of Reformed Churches and Some Classical Pentecostal Churches and Leaders 1996 - 2000. Cyberjournal for Pentecostal-Charismatic Research. [Available online at http://pctii.org/cyberj/cyberj8/WARC.html] (Accessed 21 August 2021)

Ziefle, J.R. (2012). David du Plessis and the Assemblies of God. E-Book (PDF). Published 28 September 2012. 